\title{
The Adaptive Study on College Students to Multimedia Assisted College English Teaching
}

\author{
Bangqing Pei \\ School of Foreign Languages, Mianyang Normal University, China \\ peibangqing@163.com
}

\begin{abstract}
This paper used the data from 208 college students as the study object. Through the interaction of the study method of survey report and empirical study, the study used SPSS 17.0 to analyze the data of collected. The study discussed the problems of how Chinese college students treat multi-media English teaching, which includes information literacy, learning tactics, learning method, learning attitude and so on. The result shows that Chinese college students own the basic information literacy, however, they are in a unsuitable state of English learning method, English learning tactics under the multi-media environment. According to the study result, the paper made a relevant adaptive conclusion.
\end{abstract}

Keywords: multi-media technology, college English teaching, learning tactic, fitness

\section{Introduction}

Thinking and learning only make sense in special situations. All the thinking, learning and cognition are located in special situation and there is no learning without situation [1]. Learning needs the environment that fit oneself and by means of determined, intentional, positive and consciousness practice, which includes interactive intention-action-reflection. Fit means the process of dealing with demands and challenges in learning. The process includes the change of cognitive process and affective process. We adapt to environment by adjusting behavior and countermeasures commonly. Thus, we should adjust our behavior to adjust the continuous changing learning environment.

Learning adaption means that students initiatively adjust themselves to fit the learning environment, which includes students, learning environment and change. Learning adaptability means the ability tendency that students adjust themselves to fit environment change. Multi-media technology changed the learning environment of English teaching. This paper mainly studies whether the students suit the multi-media technology.

The twenty-first century is an age of information explosion in which the speed, the amount and the extent of knowledge spreading are unparalleled in history. The relationship among countries and among people is becoming much closer. In other words, the world is much smaller than before. Therefore, it is nicknamed "the Earth Village". People's activities are not only performed in their own countries, but also in the world. So, the importance of English as an international language is obvious. The persons who can listen and speak as well as can read and write are badly needed in our society. But under the influence of traditional English teaching mode, the students can only read and write. They are called "deaf-mutes". So traditional English teaching mode is difficult to meet the needs of society. It is challenged by multimedia as a new English teaching assistance. Multimedia results from the development of 
society and modern technology and is a breakthrough of the computer assisted teaching technology.

With the deepening of quality-oriented education, the foreign language teaching idea is from regarding the teacher as the center to regarding the student as the center. The teaching method is also changing. Teachers use multimedia technology more often than before, which makes classroom instruction vivid and lovely. Through multimedia teachers can make a better educational product by putting characters, charts, sounds, cartoons, images, etc., together. In English classes, when teachers use this kind of scene, it can greatly increase the interest of students and improve the ability to accept new things of students, with a result of getting double the result with only half the effort.

\subsection{Multi-media technology and university English teaching environment}

Multimedia can best be defined as various combinations of text, graphics, sound, animation and video with links and tool that let the teacher/learner navigate, interest and communicate with the computer.

The teaching progress for human beings is to enhance and integrate the information transmitted by various sensors, such as eyes, ears, nose and hand, and then the knowledge is acquired. Trencher, an experimental psychologist, has ever done two famous psychological experiments: one is about the channels of human's getting information. That is, how human beings get information. By a large number of experiments, he has proved that the information human beings received, $83 \%$ is by sight sense, $11 \%$ by hearing sense, and $94 \%$ by combining listening with seeing. Besides, $3.5 \%$ is by smell sense, $1.5 \%$ by touch sense, and $1 \%$ by taste sense.

Another experiment is about the relationship between memories and sensors. In other words, how much man will store the received information. The result is as follows: generally speaking, man can remember $10 \%$ of what he/she just read, $20 \%$ of what he/she heard, $30 \%$ of what he/she saw, $50 \%$ of what he/she saw and heard. That is to say, the effect of study and memorizing could reach its maximum if the same topics of subjects stimulate simultaneously the sensors. The multimedia technology can be of great assistance in this sense.

Multi-media mean using computer to deal with various kinds of information to connect these information and build a system which owns interaction, whereas produce synergistic effect. In this paper multi-media technology is centered on computer, which includes multimedia classroom, language laboratory, network classroom and independent study center. They together construct good teaching environment of college English.

The function and characteristics of multi-media provide reliable support for its teaching. The interaction of multi-media is good for motivating students' learning interest and the development of cognitive effect. The diversity of external stimulation that multi-media provide is good for the achievement of knowledge and multi-media computer can help students get the most favorable environment as a cognitive tool. There are many characteristics of multi-media English teaching, which are instructional, scientific, interactive, richness, intelligent, situational and virtual [2].

Network classroom, self learning, language laboratory can be seen as a systematic software which served for college English teaching and learning. It uses stream media as the core of network English teaching courseware. Under the support of teaching management system, learners can realize self learning, individualized learning, and interactive learning and socialized learning, which changed the traditional learning method and provided better learning environment and method for learners. We should make full use of the opportunity of the development of multi-media and network technology and change the sole teaching method which focused on teachers' teaching. New teaching method should based on modern 
information technology, especially network technology, which lead the English teaching to individual learning and initiative learning which is not limited by time and location [3].

With the popularity of computers and the continuous development of English teaching software, multimedia teaching mode based on network circumstance will certainly become the main teaching method of college English teaching. The former teaching method depends on a book, a piece of chalk and a tape recorder, and the teacher's main teaching aim in class is to impart language knowledge. Nowadays, English teaching based on network circumstance brings the advantage of network into full play, and its' main aim is to impart language knowledge, study methods and application skills. So the students' interest of self-study English will be strengthened, their ability of speaking and listening to English will be also heightened.

\subsection{The Current Status of Multimedia Teaching Method in College English Teaching}

College English teaching is to set up a harmonious and high-effective teaching atmosphere in the English class to make students take part in the practice. Thus we can cultivate their listening, speaking, reading and writing abilities, which are the final teaching aimdeveloping the students' English intercommunicative ability. Here we have some questions. What is missing in our college English class? What do we want most? What is the most difficult? What problem do our teachers want to solve when using modern information technology? Of course, the answer is not the grammar, nor the word differentiation, but the real language and the real language atmosphere. Because of the powerful functions of the computer, multimedia teaching method has many advantages such as modularization, intelligence and networking which will be very helpful to college teaching method. The interaction and intelligence of the multimedia courseware become good medicine for mute English of Chinese students. With the powerful functions of the multimedia computers, students can talk with the virtual characters set by the computer. At the same time, students can correct their own mistakes according to the judge of the computers, which is beneficial to improve their ability of communication.

\subsection{The practical test of online education of the course of 'college English'}

In China, the network teaching of the course of 'college English' use the internet as the big environment and depend on campus network, supported by English teaching platform, assisted by teachers' teaching and combine the language knowledge related to campus network and internet. There should be three systems in the network teaching platform of college English, which are teaching/learning system, teaching/learning resources and teaching/learning management system. In the three big systems, the teaching/learning system is the major system, which includes five sub-systems, that is multi-media coursework system, real time guidance system, unreal time discussion system, homework submission/management system and online test system. Such system is the most common system used in college English teaching. The network classroom integrates the scattered resource and makes utilization, which can provide platform for self learning and build new English teaching method. The self learning mode of current college online English teaching can be seen in Figure 1. 


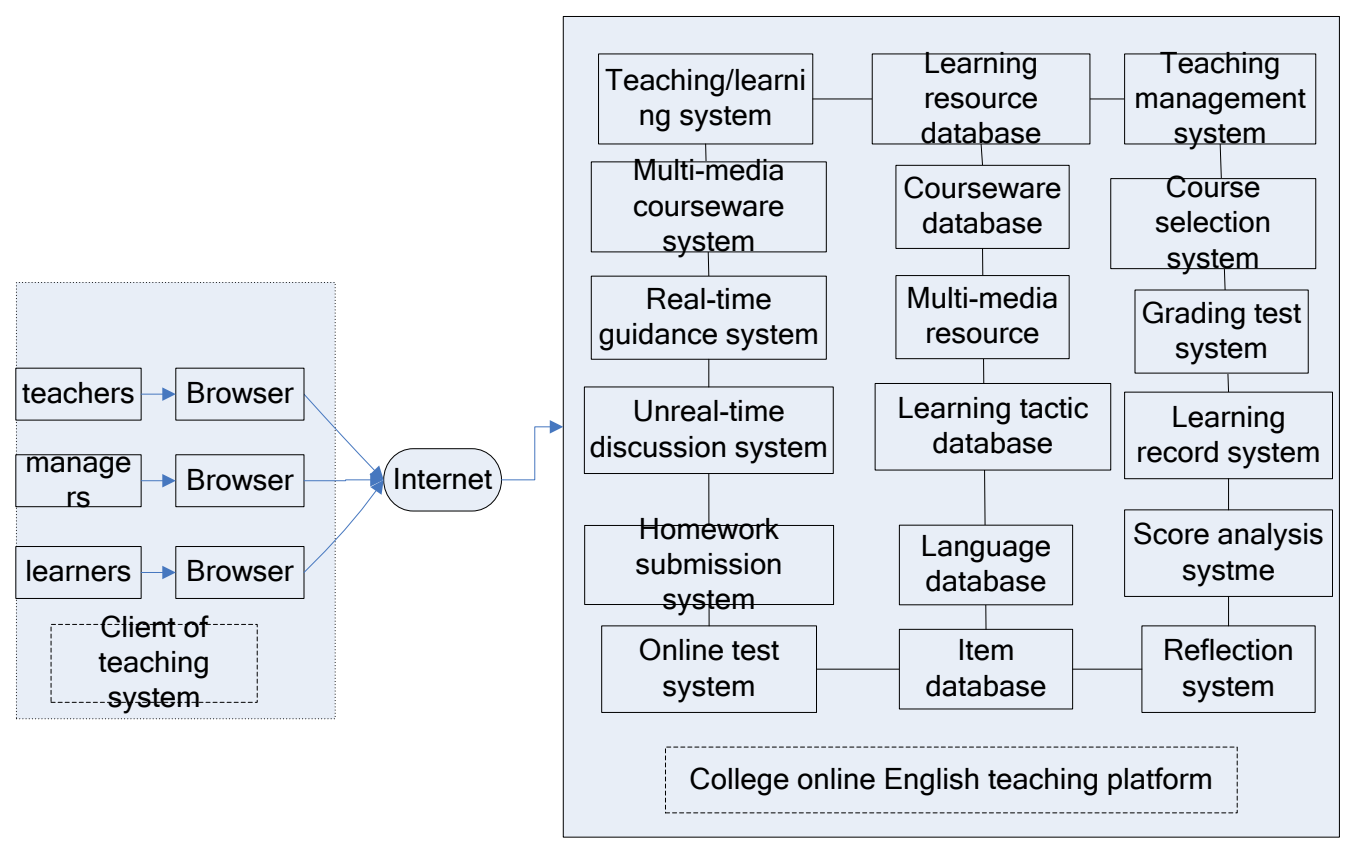

\section{Figure 1. The self learning mode of current college online English teaching}

The main model of the college network English teaching are as follows, the school made a placement test after entrance, and then arrange four class hours each week, which two are face to face teaching, and he other two in multi-media classroom. The time of fast class is one year and the slow class is two years. The big and small classes are combined. The big class mainly teaches the lessons focus, difficulties, learning tactics, fast reading and so on. The small class mainly teaches oral English. The self learning and face to face teaching are combined. Self learning mainly means that students entered self learning system after entering fixity information in network classroom. Through the self learning system, students can not only learn the same contents with face to face teaching, but also can learn different contents. Students can control their own study process and take tests on self learning system. Students can get 30 to 50 percent of credit through network self learning system.

\subsection{Problem proposition}

To sum up, the design of multi-media English teaching has become an important problem waiting to be solved by current scholars. In the practical English teaching, the paper integrates the project-based learning and cooperative learning, and designed the learning environment of network self learning. The paper mainly focused on the following problems, which are information literacy, learning resource, English learning method, learning environment, learning tactics, and learning evaluation and management.

\section{Study Method}

This paper applied the study method of survey report and empirical study.

\subsection{Samples}

In this paper, the samples are the sophomores of three universities in Guangzhou, which there are 208 students. All the three universities applied the multi-media English teaching. All 
the samples have the English learning experience in network classroom, self learning center and language laboratory. According to the principle of standard deviation is in reverse proportion to the sample size, when the samples beyond 200, the standard deviation will reduce significantly. After the samples beyond 500, the reduction will be not significant [4]. Thus, 208 samples can stand for the group of being studied. Table 1 listed the information of samples.

Table 1. The information of samples $(n=208)$

\begin{tabular}{ccccccccc}
\hline subject & & sex & & Whether & have & \multicolumn{2}{l}{$\begin{array}{c}\text { Whether have the } \\
\text { internet and } \\
\text { network }\end{array}$} & \\
\hline $\begin{array}{c}\text { Socia } \\
1 \text { science } \\
102\end{array}$ & $\begin{array}{c}\text { Natur } \\
\text { e science } \\
106\end{array}$ & male & & femal & Yes & No & Yes & No \\
\hline
\end{tabular}

\subsection{Questionnaires}

This paper consulted domestic and overseas literature and made the questionnaire of learning situation. The type of the questionnaire not only includes five Likert scale, but also includes multiple choice question and subjective questions. The contents of the questionnaire include the following things. First, it includes the fitness of students to English learning resource. The paper selected 35 items about sensory preferences in learning style profile scale, which can be seen in result analysis part. Such items are being used to test the fitness of learners to network learning environment and the relation between the preference of vision, hearing and kinesthesis of learners and the learning environment. Second, it includes the fitness of learners to learning environment. In details, it designed 16 items referring to related literature and used the likert five scale to test the fitness of students to learning resource and learning environment. From whether learner can fit the multi-media technology environment, the paper designed many levels of items of the hardware, management, utilization and evaluation of campus network in order to understand the proficiency of students to computer application. All the questionnaires are modifies several times in order to assure the reliability and validity.

\subsection{Study process}

The study made a survey for all the students in English teaching and took back the questionnaires on the spot. The study gave out 246 questionnaires in all and took back 208 effective questionnaires. Before collecting data, the study made a pretest among the students in the same grade. There are 30 students in the pretest. Through the pretest, it improved the reliability of the questionnaires. The study used SPSS 17.0 to test the reliability of the questionnaires.

\section{Result Analyses}

The result analysis is divided into three parts. The first part is the fitness of the teaching environment. The second part is the fitness of teachers. The third part is the fitness of students.

Table 2 shows the self evaluation of learners to operate English skills. From it we can see that the reading ability of the students is strong. After that is the expressive, dictation and translation ability of the students. The biggest weakness is oral English of the students. The 
standard deviation shows that the oral English level of the students is very different. Such a result provides a sally port for English teaching reform.

Table 2. the self evaluation of learners to operate English skills $(\mathrm{n}=208$, Liker five scale, Cronbach's Alpha $=0.80)$

\begin{tabular}{llcl}
\hline English skill & average & $\begin{array}{c}\text { Standard } \\
\text { deviation }\end{array}$ & Rank \\
\hline Dictation & 2.92 & 0.73 & 3 \\
Oral English & 2.72 & 0.74 & 5 \\
Expression & 2.93 & 0.73 & 2 \\
Reading ability & 3.10 & 0.74 & 1 \\
Writing ability & 2.70 & 0.68 & 7 \\
Listening & 2.71 & 0.70 & 6 \\
Comprehension & & & 4 \\
\hline Translation & 2.86 & 0.67 & 4 \\
\hline
\end{tabular}

The whole average of Table 3 is 2.82, which shows that the English learners are located in inadaptation stage. Table 6 shows the demand of English learners to self learning system under the multi-media environment. From Table 6, we can see that learning tool and tactics is the most demanding thing of students. Thus, the learning tool and tactics are the necessary things to guarantee the multi-media English teaching.

Table 7 shows the situation of English learners to use learning tactics in network learning. From Table 7 we can see that English learners lack of network learning tactics basically. It is very necessary to give students guidance and training of network learning for students.

Table 3. the fitness situation of learners to learning method

$(n=208$, Likert five scale, Cronbach's Alpha is 0.95)

\begin{tabular}{lccc}
\hline Learning method & Averag & $\begin{array}{c}\text { Standard } \\
\text { deviation }\end{array}$ & Rank \\
& $\mathrm{e}$ & 0.89 & 1 \\
Songs and movies & 3.71 & 0.98 & 2 \\
Dialogue with students & 3.45 & 1.27 & 3 \\
Dialogue with foreign teachers & 3.42 & 0.8 & 4 \\
Learning textbooks by oneself & 3.39 & 0.78 & 5 \\
Reading & 3.33 & 1.07 & 6 \\
Dialogue with teachers & 3.31 & 0.82 & 7 \\
Teachers' teaching & 3.27 & 0.86 & 8 \\
Finding English & 3.21 & & \\
information & & 0.85 & 10 \\
Learning tapes and disks & 3.14 & 0.84 & 11 \\
Dictation exercises & 3.06 & 0.98 & 11 \\
Listening videos & 3.05 & 0.88 & 13 \\
Writing & 3.05 & 0.85 & 13 \\
Tests & 3.02 & 0.79 & 15 \\
Translation & 3.02 & 0.93 & 15 \\
Utilize network resource & 3.01 & 0.86 & \\
Do homework & 3.01 & &
\end{tabular}




$\begin{array}{llll}\text { Do PowerPoint } & 2.99 & 0.85 & 17 \\ \text { Chat } & 2.98 & 0.87 & 18 \\ \text { Communication with writing } & 2.94 & 0.89 & 19 \\ \text { Group communication } & 2.91 & 1.02 & 20 \\ \text { Multi-media learning } & 2.9 & 1.12 & 21 \\ \text { Simulation } & 2.9 & 0.97 & 21 \\ \text { Network classroom } & 2.83 & 1.15 & 23 \\ \text { Oral communication } & 2.8 & 0.86 & 24 \\ \text { Language laboratory } & 2.7 & 1.21 & 25 \\ \text { Teachers' teaching individually } & 2.7 & 1.1 & 25 \\ \text { English corner } & 2.66 & 1.02 & 27 \\ \text { Self learning of network resource } & 2.62 & 0.83 & 28 \\ \text { Electronic library } & 2.58 & 1.07 & 29 \\ \text { English intensive training class } & 2.43 & 1.12 & 30 \\ \text { Tutorial class } & 2.4 & 1.06 & 31 \\ \text { Chat room } & 2.38 & 1 & 32 \\ \text { Online English homework } & 2.36 & 0.92 & 34 \\ \text { E-mail } & 2.36 & 0.95 & 34 \\ \text { English party } & 2.36 & 1.07 & 34 \\ \text { English competitions } & 2.36 & 0.95 & 34 \\ \text { Cooperative learning on network } & 2.31 & 1 & 39 \\ \text { Online English } & 2.3 & 0.93 & 40 \\ \text { Speaking competitions } & 2.2 & 0.89 & 41 \\ \text { English forum } & 2.15 & 0.94 & 42 \\ \text { meetings } & 2.09 & 1.07 & 43 \\ \text { English debating } & 2.35 & 1.02 & 38 \\ \text { others } & 2.37 & 1.03 & 33 \\ \text { Average } & 2.81 & & \end{array}$

Table 4. the most favorable way of English communication of learners

( $n=208$, multiple choices)

\begin{tabular}{lll}
\hline Communication way & Percentage (\%) & Rank \\
\hline Writing & 54 & 1 \\
Face to face & 51 & 2 \\
Online chat without video & 49 & 3 \\
E-mail & 44 & 4 \\
QICQ & 33 & 5 \\
Messages & 25 & 6 \\
BBS & 25 & 7 \\
Online chat by video & 19 & 8 \\
Cell phone & 11 & 9 \\
\hline
\end{tabular}


Table 5. the causes that learners can not fit multi-media English teaching

\begin{tabular}{lcc}
\hline Causes & Percentage & Rank \\
& $(\%)$ & 1 \\
Visual fatigue & 45 & 2 \\
Cannot control the process & 38 & 3 \\
Lack of learning tactics & 36 & 4 \\
Lack of self-control ability & 34 & 5 \\
Worry about useless & 27 & 6 \\
Unused to it & 26 & 7 \\
Unskilled & 25 & 8 \\
Worry about internet addiction & 19 & 9 \\
No computer & 18 & 9 \\
Do not know how to seek help & 18 & 11 \\
Think it should combine with other methods & 18 & 12 \\
Think it can not get good effect & 15 & 13 \\
Like traditional way & 14 & 14 \\
Think it is more harm than good & 11 & 15 \\
Nervous & 8 & 16 \\
Invasion of privacy & 6 & 17 \\
Has no difference with traditional method & 4 & 18 \\
Do not like video & 3 & \\
\hline
\end{tabular}

Table 6. the demand of learners for self learning system

\begin{tabular}{lll}
\hline Items & Percentage & Rank \\
\hline Method guidance & 54 & 1 \\
Confidence enhancement & 42 & 2 \\
Learning plan & 38 & 3 \\
Operation skill training & 34 & 4 \\
Self learning completely & 33 & 5 \\
Supervision tools & 32 & 6 \\
\hline
\end{tabular}

Table 7. Usage situation of learning tactics of network learning

\begin{tabular}{llll}
\hline \multirow{2}{*}{ Learning method } & \multicolumn{2}{l}{ Usage situation } & \\
\cline { 2 - 4 } & Often & At times & Seldo \\
\hline Writing the contents of network class & $10 \%$ & $30 \%$ & $42 \%$ \\
Do exercises after reading & $24 \%$ & $36 \%$ & $27 \%$ \\
Make study plan before computer time & $10 \%$ & $32 \%$ & $51 \%$ \\
Make brief summary & $11 \%$ & $30 \%$ & $43 \%$ \\
Self examination of the process & $16 \%$ & $42 \%$ & $31 \%$ \\
continuously & & & \\
Self examination of learning method & $22 \%$ & $40 \%$ & $18 \%$ \\
\hline
\end{tabular}




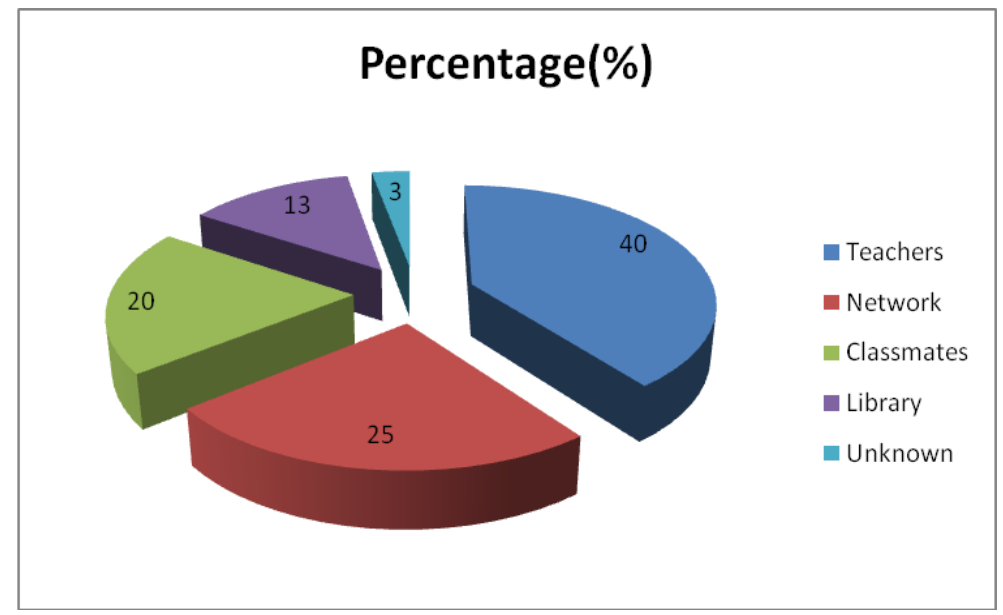

Figure 2. The most favorable way of seeking help in learning English

Figure 2 shows the most favorable ways of students to seek help in learning English. From Table 8 we can see that when students came across questions, the most common way they seek for help is face to face guidance by teachers. Thus, in English learning, it should strengthen the interaction between students and teachers face to face.

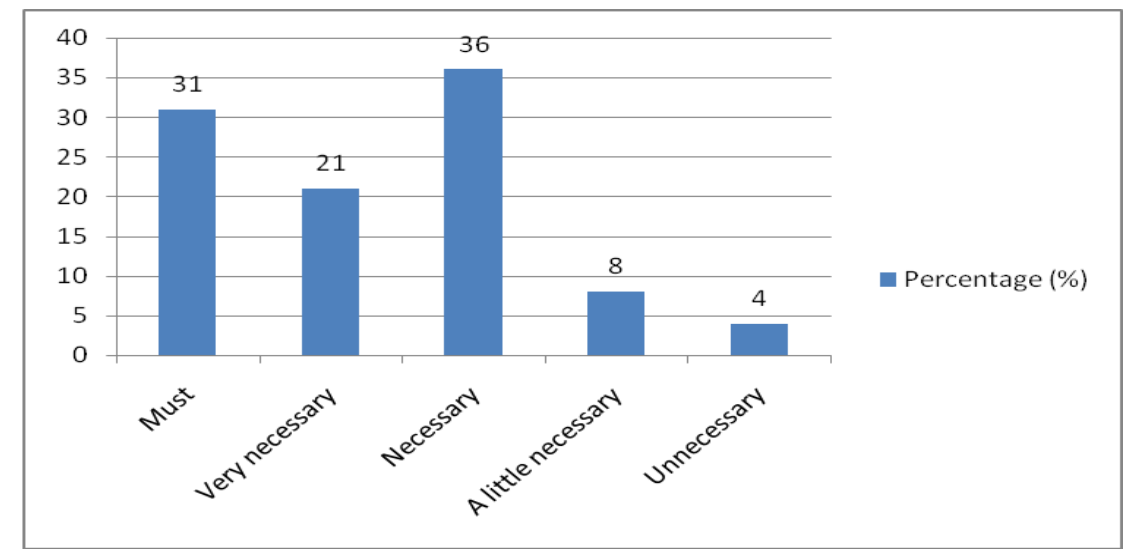

Figure 3. The necessary of introducing college network English teaching

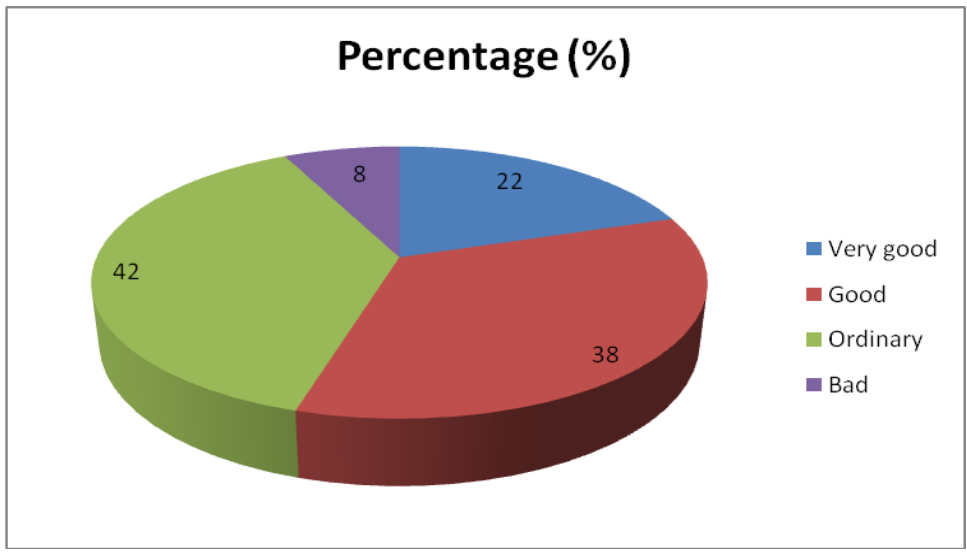

Figure 4. The evaluation of the effect of multi-media English teaching 
Figure 4 shows that English learners hold a positive attitude to multi-media English teaching, however, the effect of multi-media is not as good as we expected.

\section{Table 8. the regression analysis between the computer proficiency of learners} and the effect of college multi-media English learning

\begin{tabular}{llll}
\hline $\begin{array}{l}\text { Independent } \\
\text { variables }\end{array}$ & Beta & T value & P value \\
\hline Windows & 0.035 & 0.209 & 0.835 \\
Word/office & 0.144 & 0.870 & 0.387 \\
PowerPoint & -0.135 & -0.973 & 0.333 \\
Author ware & 0.035 & 0.282 & 0.779 \\
Excel & -0.037 & -0.239 & 0.812 \\
FrontPage & -0.199 & -1.430 & 0.156 \\
Flash & 0.040 & 0.286 & 0.775 \\
E-mail & -0.198 & -1.419 & 0.159 \\
Information & 0.472 & 2.409 & 0.018 \\
search & & & \\
\hline
\end{tabular}

In table 8 we can see that the proficiency of computer has a positive significant prediction effect on the evaluation of the effect of college multi-media English teaching.

\section{Discussions}

From the above analysis, we can see that students own the basic information literacy, which make the multi-media English learning to be technical feasibility. But students tend to have an inadaptation state to learning method and tactics. The factors that affect multi-media English teaching are as follows, which are the difference of learning motivations, lack of network learning tactics, lack of cognitive learning tactics and lack of self-monitoring tactics.

The fifth factor that affects the college multi-media English teaching is the lag of teaching method. Although there is new technology, new teaching environment, it does not renew the teaching method, which also focused on classroom, textbook and teachers.

The sixth factor is the difference of learning resource. Owing to the reasons of technology or economic aspect, in building learning platform and network course, the development of learning tool and the guidance of learning tactics are not enough. It also lacks of enough monitor of learning process.

The seventh factor is the support of learning environment. The learning environment here means the internet conditions of learners, such as home, campus, company, and net bar and so on. The stability of the internet also affects the multi-media English teaching.

Since network learning owns the characteristics of initiation, independence and openness, the motivation of learners has a direct proportion to learning effect. If the learners lack of learning motivation, they can not get good effect. On the other hand, since the learners are completely free and have no pressure or monitor, and the internet is full of attractions, which made students can not go on studying. This will run counter to the truly self learning.

Current cognitive psychologist indicates that there is no teaching target can compare with make students to be independent, automatic and efficient learners. Thus, change the study method of college students and encourage students learn by themselves has become more and more important in current college English teaching. It should change the traditional teaching method which focused on teachers, classrooms and textbooks. Whereas the learning tactic 
teaching is the necessary condition to guide students learn by themselves, which is an important way to improve the learning efficiency of college students.

The definition of learning tactics differs with different scholars. As a tactic, Bruner defines it as when a person came across problems, he or she can use the old knowledge to deal with problems in order to finish the objects [5]. From this, we can see that tactic is a big object or plan. Zhou Yangen pointed out that learning tactic teaching is an important way to promote self learning [6]. The learning tactic teaching includes cognitive tactic teaching, meta cognition tactic teaching and resource management tactic teaching. Cognitive tactic is the basis of the development of self learning ability of students. Meta cognition tactic teaching is the key of the development of self learning ability of students. Resource management tactic is the guarantee of the development of self learning. Thus, the paper makes the following suggestions.

First, strengthen the cognitive tactic. Flavell indicates that meta cognition refers to the cognitive process, which includes the monitoring and adjustment of cognitive process [7]. Meta cognition is the key point of learning tactic teaching. People call all the tactics of self monitoring tactic, self guidance tactic, self evaluation tactic and self adjustment tactic to be meta cognitive learning tactic.

Second, train the self monitoring ability. In order to ensure the success of learning, learners must make plan, check, evaluation, reflex, control and adjustments, which called learning monitoring. The core part is the training of meta cognitive ability, which is the self-awareness and self-reflection of cognitive activities. English teachers should guide students to make suitable attributions in order to eliminate the attributive errors.

Third, update learning ideas. In order to change the learning method and ideas of learners, it demands to pay enough attention to the function of network and change the habits of using internet as a recreation tool. Learners should form a habit of using the internet to get learning resources and useful information, only by this can make learners focus on learning process.

Fourth, make qualitative learning targets. Self learning needs to strengthen the learning motivation and clear learning targets. Phil Benson indicates that the foundation of self learning is the interest of learners [8]. Learning motivation determines the learning targets and learning targets determines the learning contents, which can also be used to evaluate the effect of learning. When making learning targets, teachers should give students a suitable learning target according to students' demand. The design of multi-media English teaching should split the learning targets and make quantitative targets for each subject.

Fifth, reflect the learning plan. Learners need self motivation, independent study and self management. They should apply the construct knowledge into solving complex problems and monitor and reflect the solving process. Scott indicates that reflection is an effective tool to improve the self control ability [9]. Thus, in order to make good control of the learning process, multi-media English learners should reflect the learning plan constantly.

Sixth, make a good evaluation system. Bandura indicates that self-efficacy determines people's selection of activities and the persistence of the activities [10-12]. It also affects the attitude of learners and the obtainment of new behaviors. Self-efficacy is the direct key variable that affects self control. Learners should be good at obtaining the reflective information of each channel, just as the discussion of partners, the hints of teachers, exercises, self examination and so on. Only by correct evaluation of its learning effect can students get good result. 


\section{Conclusions}

In a word, multimedia teaching method belongs to CAI (computer-aided instruction) in substance, and we can heighten efficiency substantially, which is a kind of trend. We should make best use of its advantages and bypass its disadvantages. Of course it can't replace all other teaching methods and we can apply several methods together in one class. Only under the background of quality education can we use advanced educational theory and we can fulfill the target of college English teaching by utilizing modern education technology reasonably.

Multi-media English teaching not only make students learn special knowledge, but also can guide students to get good learning tactics to meet the demand of self learning and lifelong learning. This paper mainly made the adaptive study on university students to multimedia assisted university English teaching use the method of empirical study. From the analysis, we can see that there still exist many problems of current multi-media English teaching in colleges, such as lack of learning tactics, difference of learning motivations, lack of cognitive tactics and lack of self monitoring tactics. Thus, the study make the following suggestions for the current multi-media English teaching of colleges, which are strengthen the cognitive tactic of learners, train the self monitoring ability of learners, update the current learning ideas of learners, make qualitative learning targets for learners, reflect the learning plan of learners constantly, make a good evaluation system for learners.

\section{Acknowledgements}

At the point of finishing this paper, I'd like to express my sincere thanks to all those who have lent me hands in the course of my writing this paper. First of all, I'd like to take this opportunity to show my sincere gratitude to my supervisor, Prof. Wu Shuqi, who has given me so much useful advice on my writing, and has tried their best to improve my paper. Secondly, I'd like to express my gratitude to my colleagues who offered me references and information on time. Last but not least, I'd like to thank those leaders, teachers and working staff in Mianyang Normal University and especially those in the School of Foreign Languages. Without their help, it would be much harder for me to finish my study and this paper.

\section{References}

[1] B. G. Wilson and K. M. Myers, "Situated Cognition in Theoretical and Practical Context", In Theoretical Foundations of Learning Environments, (2000), pp. 185-192.

[2] H. Gaoda, "Modern education technology and modern foreign language teaching", Guangxi Education Press, China, (2002).

[3] C. Liping, "Tactic training and foreign language teaching", Hehai University Press, China, (2004).

[4] T. Anderson and F. Elloum, "Theory and Practice of Online Learning", Athabasca University Press, Canada, (2005).

[5] J. Bruner, "The Process of Education", Cambridge, MA: Harvard University Press, USA, (1960).

[6] Z. Yangen and S. Qingsong, "The study on the multi-media English teaching of colleges", Foreign Language Teaching and Study, vol. 9, no. 2, (2003), pp. 43-49.

[7] J. H. Flavel, "Developmental Changes in Memorization Processes", Cognitive Psychology, vol. 1, no. 4, (1970), pp. 23-25.

[8] P. Benson, "Teaching and Researching Autonomy in Language Learning", Person Education Press, China, (2001).

[9] S. G. Paris and L. R. Ayres, "Becoming Reflective Students and Teacher", American Psychological Association, USA, (1994).

[10] L. Rui-ji, "Investigation and Study on Students' Degree of Satisfaction of Multimedia Teaching", JCIT: Journal of Convergence Information Technology, vol. 7, no. 11, (2012), pp. 262-270. 
[11] L. Ruiji, "The Development on Multimedia Teaching Resources based on Information Processing Theory", IJACT: International Journal of Advancements in Computing Technology, vol. 4, no. 2, (2012), pp. 58 -64.

[12] J. D. Teasdale, "Self-efficacy: Toward a Unifying Theory of Behavior Change?", Advances in Behaviour Research and Therapy, vol. 1, no. 4, (1978), pp. 211-215.

[13] R. Ellis, "The Study of Second Language Acquisition”, Oxford University Press, (1994).

[14] M. Haughey, "Pan-Canadian Education Research", Ottawa Canadian Society for Education, (2000), pp. 121.

[15] C. A. Chapelle, "Computer Applications in Second language Acquisition: Foundations for Teaching", Testing and Research, Cambridge University Press, (2001).

[16] H. G. Widdowson, “Aspects of Language Teaching”, Oxford University Press, (1983).

[17] I. Thompson and J. Rubin, "Can strategy instruction improve listening comprehension?", Foreign Language Annals, vol. 29, no. 3, (1996).

[18] D. Chun, "using computer networking to facilitate the acquisition of interactive competence", System, (1994).

[19] J. S. Lamancusa, J. E. Jorgensen, J. L. Zayas-Castro and J. Ratner, "The Learning Factory- A New Approach toIntegrating Design and Manufacturing into Engineering Curricula”, 1995 ASEE Conference Proceedings, (1995) June 25-28, Anaheim, CA, pp. 2262-2269.

[20] C. L. Hidalgo and J. R. Williams, "WEB-ducation: Extending a Teacher's Communication and Mediation Capabilities through the Internet", Engineering Education Innovators Conference, sponsored by NSF, (1996) April 7-8, Washington D.C., http://monett.mit.edu/nsf/trpdoc.nsf.

[21] S. R. Lerman and J. N. Lapierre, "A Multimedia Model on Statistics in Manufacturing Quality Control", Engineering Education Innovators Conference, sponsored by NSF, (1996) April7-8, http://wwwceci.mit.edu/projects/manufacturing/CEPsummary.html.

[22] P. L. Jackson, "OPTLINE: Manufacturing Process Line Simulation", Engineering Education Innovators Conference, NSF, (1996) April 7-8, Washington D.C., http://www.orie.cornell.edu/ jackson/optline.html.

[23] J. E. Wood, H. Hahn, P. Kunsberg, H. Ravinder and J. N. Beer, "The UNM Manufacturing Engineering Program: Manufacturing Enterprise Simulator", Engineering Education Innovators Conference, sponsored by NSF, (1996) April 7-8, Washington D.C., http://www-mep.unm.edu/Paper97_TRP1221.htm.

[24] J. S. Lamancusa, M. Torres, V. Kumar and J. Jorgensen, "Learning Engineering by Product Dissection”, 1996 ASEE Conference Proceedings, (1996) June 23-26, Washington, DC.

[25] L. Morrel, J. Zayas, J. S. Lamancusa and J. E. Jorgensen, "Making a Partnership Work: Outcomes Assessment of a Multi-Institutional, Multi-Task Project", Engineering Education Innovators Conference, NSF, (1996) April 7-8, Washington D.C., URL: http://mayaweb.upr.clu.edu/Paper/techno.html.

[26] Authorware from Macromedia, Inc., 600 Townsend St., San Francisco, Ca., 94103.

\section{Author}

Bangqing Pei. He received his B.A (1998) and M.Ed in (2005) from University. Now he is full lecturer at School of Foreign Languages, Mianyang Normal University, China. Since 1998 he has been an English teacher in Mianyang Normal University. His current research interests include different aspects of English language teaching. 
International Journal of Multimedia and Ubiquitous Engineering Vol.8, No.5 (2013) 